\title{
The relationship between dairy products intake and breast cancer incidence: a meta- analysis of observational studies
}

Yujing $\mathrm{He}^{1 \dagger}$, Qinghua Tao ${ }^{2 \dagger}$, Feifei Zhou' ${ }^{1}$ Yuexiu Si ${ }^{3}$, Rongrong Fu' ${ }^{4}$, Binbin $\mathrm{Xu}^{5}$, Jiaxuan $\mathrm{Xu}^{1}$, Xiangyuan $\mathrm{Li}^{1}$ and Bangsheng Chen ${ }^{2 *}$

\begin{abstract}
Background: The effect of dairy products intake on breast cancer (BC) is highly controversial. This study aims to investigate the relationship between dairy intake and $B C$ incidence.

Methods: A search was carried out in PubMed, EBSCO, Web of Science, and Cochrane Library databases before January 2021. The primary objective was the risk of BC and intake of dairy products were exposure variables.

Results: The meta-analysis comprised 36 articles with 1,019,232 participants. Total dairy products have a protective effect on female population (hazard ratio $(H R)=0.95,95 \%$ confidence interval $(C l)=0.91-0.99, p=0.019$ ), especially for estrogen receptor-positive $(E R+)(H R=0.79, p=0.002)$ and progesterone receptor-positive $(P R+) B C(H R=0.75$, $p=0.027)$. For $E R+/ P R+B C$, there is a trend of protection, but it has not reached statistical significance $(H R=0.92$, $p=0.075)$. Fermented dairy products can reduce $\mathrm{BC}$ risk in postmenopausal population $(\mathrm{HR}=0.96,95 \% \mathrm{Cl}=0.93-$ $0.99, p=0.021$ ), but have no protective effect on premenopausal population ( $\mathrm{HR}=0.98,95 \% \mathrm{Cl}=0.94-1.03, p=0.52)$. Non-fermented dairy products have no significant effect on BC occurrence $(p>0.05)$. High-fat dairy products are harmful to women, without statistical difference $(\mathrm{HR}=1.06,95 \% \mathrm{Cl}=1.00-1.13, p=0.066)$. On the contrary, low-fat dairy products can protect the premenopausal population ( $\mathrm{HR}=0.94,95 \% \mathrm{Cl}=0.89-1.00, p=0.048)$.

Conclusion: The intake of dairy products can overall reduce $B C$ risk in the female population, but different dairy products have varying effects on different $B C$ subtypes and menopausal status.
\end{abstract}

Keywords: Breast cancer, Dairy products, Risk assessment, Meta-analysis

\section{Introduction}

Breast cancer $(\mathrm{BC})$ remains a worldwide public health dilemma [1-4]. Based on the latest GLOBOCAN data, female $\mathrm{BC}$ has surpassed lung cancer as cancer with the highest incidence worldwide [5]. Meanwhile, BC is also the most common cause of death in women [6-8]. Both endogenous factors (genetic inheritance [9] and genetic

\footnotetext{
*Correspondence: glh19920213@163.com

${ }^{+}$Yujing He and Qinghua Tao contributed equally to this work.

${ }^{2}$ Emergency Medical Center, Ningbo Yinzhou No. 2 Hospital, Ningbo, Zhejiang, China

Full list of author information is available at the end of the article
}

mutations [10]) and exogenous factors (lifestyle [11], environmental factors [12], and reproductive factors [13, 14]) can influence the $\mathrm{BC}$ occurrence $[2,3,15]$.

Nutrition and lifestyle habits are among the most easily modifiable aspects of people's lives which are considered effective prevention strategies for cancer [16-19]. On the one hand, lifestyle habits such as maintaining circadian stability [20], reducing sedentary behavior [21], little alcohol consumption [22], and little smoking [23] are considered to reduce $\mathrm{BC}$ risk. On the other hand, diet choices have an impact on health and cancer incidence rate [24]. Numerous studies on the relationship

(c) The Author(s). 2021 Open Access This article is licensed under a Creative Commons Attribution 4.0 International License, which permits use, sharing, adaptation, distribution and reproduction in any medium or format, as long as you give appropriate credit to the original author(s) and the source, provide a link to the Creative Commons licence, and indicate if changes were made. The images or other third party material in this article are included in the article's Creative Commons licence, unless indicated otherwise in a credit line to the material. If material is not included in the article's Creative Commons licence and your intended use is not permitted by statutory regulation or exceeds the permitted use, you will need to obtain permission directly from the copyright holder. To view a copy of this licence, visit http://creativecommons.org/licenses/by/4.0/. The Creative Commons Public Domain Dedication waiver (http://creativecommons.org/publicdomain/zero/1.0/) applies to the data made available in this article, unless otherwise stated in a credit line to the data. 
between diet and $\mathrm{BC}$ have recently been conducted [25, $26]$. For instance, plant-based dietary pattern [27, 28], low-fat dietary pattern [29], "Prudent" dietary pattern [30], and Mediterranean diet [31] were inversely associated with $\mathrm{BC}$ risk. In addition, several studies have been conducted on the effects of dairy products [32], soy products [33], fruits [34], vegetables [35], dietary fiber [36], and mushrooms [37] on BC risk rates.

Numerous studies regarding the impact of dairy products on BC risk rates remain inconsistent [38-40]. Valeria Pala et al. [41] found inconsistent correlations between $\mathrm{BC}$ risk and dairy products, whereas $\mathrm{McCul}$ lough $\mathrm{ML}$ et al. [40] discovered an inverse relationship between daily consumption of two or more servings of dairy products and $\mathrm{BC}$ risk. Kato I et al. [42] conducted a study on the impact of dairy products on $\mathrm{BC}$ and concluded that dairy products increase BC risk, while Emmanuelle Kesse Guyot et al. [43] found that BC risk was lower in those with high total consumption of dairy. In addition, there is controversy in the findings of studies regarding the impact of various dairy types (fermented dairy products, high-fat dairy products, etc.) on BC risk rates and the effect of the same type of dairy products on risk rates of various $\mathrm{BC}$ subtypes (estrogen receptor-positive $(E R+)$, progesterone receptor-positive (PR+), etc.) $[44,45]$.

Besides that, dairy products contain complex nutritional components, and their consumption is widespread in daily life [46]. Many studies have indicated that dairy products may also impact health problems such as obesity [47], diabetes [48, 49], cancer [50], and coronary heart disease $[51,52]$, but whether dairy products play a protective or harmful role against $\mathrm{BC}$ occurrence in female population is still controversial.

To provide preventive strategies for BC-related dietary choices more scientifically, statistical analysis of the available research data is now urgently required to provide reliable evidence for the association between intake of dairy products and $\mathrm{BC}$ risk. Therefore, this study aimed to evaluate the association between intake of dairy products and $\mathrm{BC}$ risk through meta-analysis.

\section{Materials and methods}

\section{Article source and search strategy}

A search of relevant studies investigating the relationship between dairy products and BC published before January 2021 was carried out in PubMed, EBSCO, Web of Science, and Cochrane Library databases. The keywords we used for searching were "breast cancer" and "dairy". The complete retrieval formula used to identify the number of studies were ("breast cancer" OR "breast neoplasms" OR "BC") AND ("dairy" OR "dairy products" OR "milk"). When referencing duplicated literature, the original article was included if the studies were published as an abstract and original article. In addition, if a single study published several articles, only the most recent or the highest quality article was included. The reference lists of retrieved studies and recent reviews have also been reviewed to examine potential inclusive studies. This meta-analysis was conducted according to the Meta-Analysis of Observational Studies in Epidemiology (MOOSE) guidelines [53]. The population, intervention/exposure, comparison, outcome, and setting (PICOS) criteria were used to describe the research question.

\section{Eligibility criteria}

Specific eligible criteria were formulated as follows: inclusion criteria: (1) all included studies are cohort and case-control studies limited to clinical studies only. (2) The main exposure of study was dairy products, and the outcome was BC risk. (3) All studies included available data about hazard ratio (HR) and corresponding 95\% confidence interval $(\mathrm{CI})$.

Exclusion criteria: (1) the study had no reference value or control group. (2) The study was conducted on BC population and used mortality or recovery rate as the outcome. (3) The study was not published in English. (4) The study did not contain a full-text article.

\section{Data extraction}

A jointly agreed data collection form was used to extract all data. In order to ensure the objectivity and accuracy of the entered data, two investigators independently extracted data from each study. A third investigator resolved disagreements. Information was extracted as follows: the author's name, year of publication, study type, country where the study was done, age, follow-up time, number of participants, number of BC cases identified in the study period, dairy type, and outcomes.

\section{Objectives, outcomes and dairy exposures}

The primary objective was the risk of $\mathrm{BC}$ and intake of dairy products were exposure variables. The second objective is to explore the effects of various dairy products, including fermented dairy products, non-fermented dairy products, high-fat dairy products and low-fat dairy products, on the incidence of BC. Fermented dairy products refer to acidic dairy products, such as yogurt, cheese, and cream created by fermenting raw milk with lactic acid bacteria or co-fermenting lactic acid bacteria with yeasts using specific microorganisms. Nonfermented dairy products are characterized as those not fermented by microorganisms, such as milk and butter. High-fat dairy products are defined as those with up to $3-5 \%$ fat per $100 \mathrm{~g}$ of food. Low-fat dairy products were defined as those with a fat content of $1.0-1.5 \%$ per $100 \mathrm{~g}$ food and nonfat dairy products with a fat content of less 
than $0.5 \%$ per $100 \mathrm{~g}$ food. HRs after adjustment for some potential confounderswere uniformly adopted in this meta-study to facilitate the processing of relevant data from the included articles. Common potential confounders include age, exercise, body mass index (BMI), oral contraceptive use, age of menarche, age of menopause, parity, family history of $\mathrm{BC}$, smoking status and alcohol intake.

\section{Bias risk and study quality assessment}

The quality of each included study was evaluated and scored using the Newcastle-Ottawa Quality Assessment Scale (NOS) checklist, a tool used for quality assessment of non-randomized studies, which is composed of eight items classified into three aspects, including selection, comparability, and outcome. The maximum scores of this checklist were nine, and scores between six and nine were identified to higher study quality.

\section{Statistical analysis}

The Stata software version 12 (StataCorp, College Station, Texas, USA) was used to analyze the data. $P$-values less than 0.05 were considered statistically significant. Heterogeneity across included studies was tested by Q statistic and $\mathrm{I}^{2}$ statistic, which is a quantitative measure of inconsistency assessment. Following the Cochrane Manual and study characteristics, $\mathrm{I}^{2}$ values between 0 and $30 \%$ indicated mild or insignificant heterogeneity, those between 30 and $70 \%$ indicated moderate heterogeneity, while those between 70 and 100\% indicated high or significant heterogeneity [54].

The CI of HR was set at 95\% to examine the relationship between dairy consumption and BC risk. A random-effect model was employed to incorporate data due to the inclusion of different dairy products to increase the credibility of results. When more than ten $[55,56]$ studies were included, sensitivity analysis and publication bias test were performed to evaluate the stability and reliability of the results. Begg's rank correlation [57] and Egger's linear regression tests [58] were used to testing publication bias.

\section{Results}

\section{Literature search}

A total of 16,912 relevant articles were identified based on retrieval formula described in the methods section by initial search in PubMed, EBSCO, Web of Science, and Cochrane Library database. No additional records were identified through other sources. A total of 9334 duplicated articles were removed, and 7139 articles were excluded according to their titles or abstracts. The remaining 439 articles were scrutinized through full-text reading. Among them, 403 articles were eliminated because of no dairy control group
( $n=230)$, non-cohort or case-control study $(n=163)$, non-original articles $(n=8)$, and non-English language $(\mathrm{n}=2)$. Eventually, 36 articles $[24,39-45,59-86]$ composed of 1,019,232 participants were selected for this meta-analysis. Figure 1 shows the flow diagram about the selection of articles.

\section{Study characteristics}

All articles were observational studies that record the $\mathrm{BC}$ risk in women with dairy products as the exposure factor. Of the 36 included studies, 14 were cohort studies (912,975 participants and 25,097 BC cases), and 22 were case-control studies $(106,257$ participants and 18,543 BC cases). Among them, 13 studies were conducted in Europe, 11 in North America (9 studies were conducted in the United States), 11 in Asia, and 2 in South America. All studies were published between 1986 and 2020, with follow-up periods ranging from 1.5 to 22.2 years. Most studies do not make special requirements for included participants, two studies were only conducted on nurses, and one study was only conducted in premenopausal population. Regarding age at recruitment, five studies did not set an upper age limit, and two studies did not set a lower age limit. In addition, the adjustment of potential confounding factors varied in different studies. Common adjustment parameters in the included studies included age, BMI, family history of BC, hormone replacement therapy (HRT), reproductive factors, total energy intake, smoking, and alcohol drinking. In order to collect data and evaluate relevant exposure factors, 21 studies chose a food frequency questionnaire (FFQ), 11 studies selected a diet questionnaire, and 3 studies chose a home visit or in-depth interview. Table 1 and Supplementary Table 1 contain detailed characteristics of the included studies.

\section{Analysis about the effect of total dairy products on BC}

Twenty-five (726,673 participants) studies recorded data about $\mathrm{BC}$ risk of total dairy products on female population, with 30,334 participants newly diagnosed with $\mathrm{BC}$ over the follow-up time. The analysis indicated that those who consumed dairy products had a significantly lower $\mathrm{BC}$ risk than those who never or rarely consumed dairy products $(\mathrm{HR}=0.95,95 \% \mathrm{CI}=$ $0.91-0.99, p=0.019)$ with moderate heterogeneity $\left(\mathrm{I}^{2}=62.3 \%\right)$, indicating that dairy product intake was protective for female population and can reduce $\mathrm{BC}$ risk. However, the consumption of dairy products has no effect on premenopausal $(\mathrm{HR}=1.02,95 \% \mathrm{CI}=$ $0.97-1.09, p=0.37)\left(\mathrm{I}^{2}=5.3 \%\right)$ and postmenopausal women $\quad(\mathrm{HR}=1.00, \quad 95 \% \quad \mathrm{CI}=0.97-1.04, \quad p=0.83)$ $\left(\mathrm{I}^{2}=0 \%\right)$. Four studies $(185,355$ participants $)$ were grouped by ER status, three studies $(87,569$ participants) were grouped by PR status, and five studies 


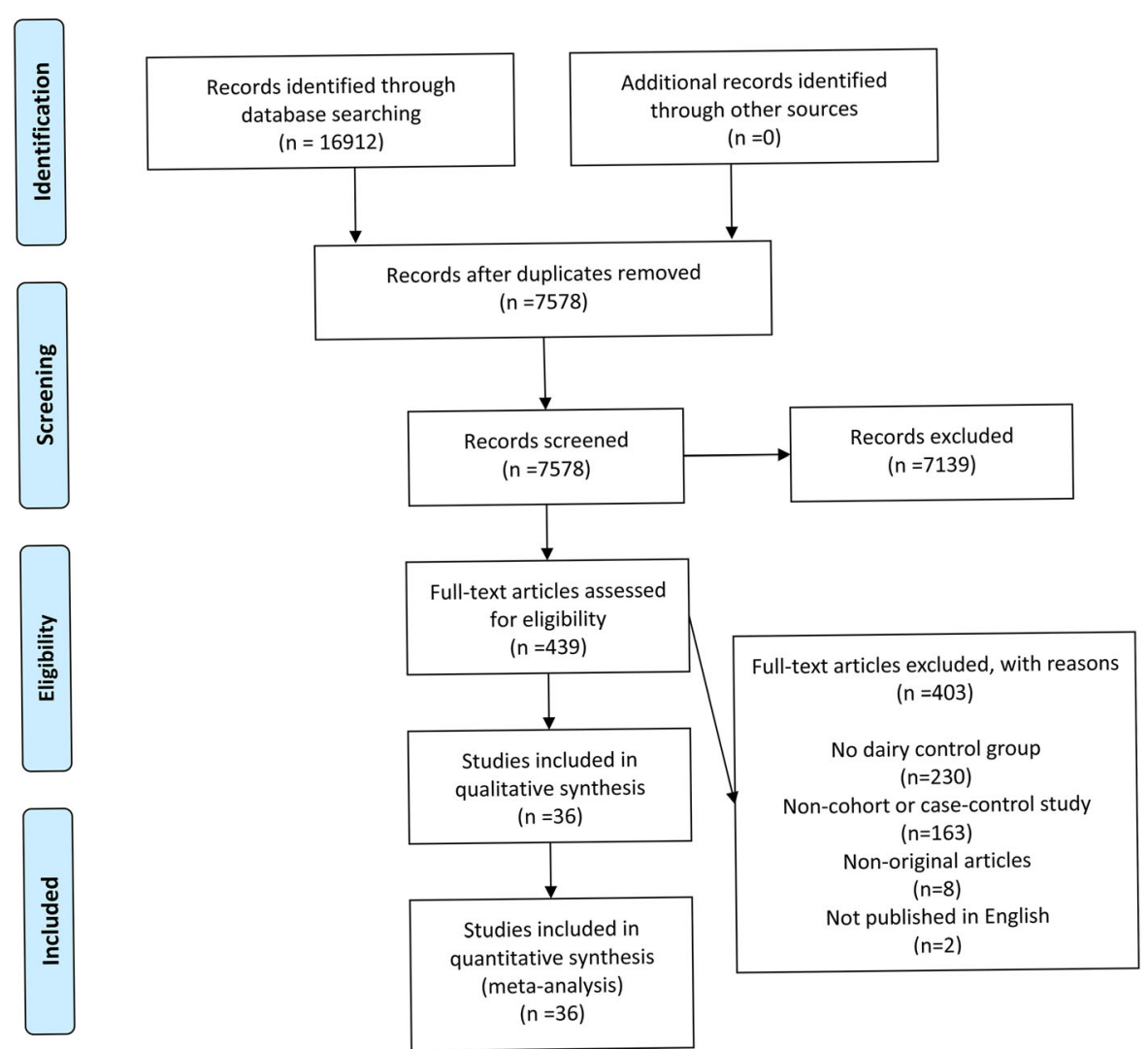

Fig. 1 A schematic flow for the selection of articles included in this meta-analysis

(184,989 participants) were grouped by hormone receptor status (included ER and PR). The metaanalysis found that consuming dairy products significantly reduces the risk of hormone-receptor-positive $\mathrm{BC}$, either $\mathrm{ER}+\mathrm{BC}(\mathrm{HR}=0.79, p=0.002)$ or $\mathrm{PR}+\mathrm{BC}$ $(\mathrm{HR}=0.75, p=0.027)$. For $\mathrm{ER}+\mathrm{PR}+\mathrm{BC}$, a trend was observed towards lower risk with consuming dairy products, but the difference was not statistically significant $(\mathrm{HR}=0.92, p=0.075)$. In addition, the consumption of dairy products had no effect on the incidence of ER- $\mathrm{BC}(\mathrm{HR}=1.06, p=0.42)$, PR- $\mathrm{BC}$ $(\mathrm{HR}=1.05, p=0.56)$ and $\mathrm{ER}-/ \mathrm{PR}-\mathrm{BC}(\mathrm{HR}=0.96$, $p=0.36)$ BC. Table 2 contains the detailed data.

\section{Analysis about the effects of fermented dairy products on BC}

In terms of fermented dairy products, 14 studies (496,747 participants) were conducted on female populations, six of which $(50,815$ participants) were grouped by menopause status, and two of which $(561,870$ participants) were grouped by hormone receptor status (ER and PR). During the follow-up period, 16,280 participants were newly diagnosed with $\mathrm{BC}$. The analysis demonstrated that fermented dairy products were not statistically significantly protective for women $(\mathrm{HR}=$ $0.98,95 \% \mathrm{CI}=0.95-1.02)$, nor for $\mathrm{ER}+/ \mathrm{PR}+\mathrm{BC}(\mathrm{HR}=$ $1.01,95 \% \mathrm{CI}=0.97-1.05)$ or $\mathrm{ER}-/ \mathrm{PR}-\mathrm{BC} \quad(\mathrm{HR}=1.03$, $95 \% \mathrm{CI}=0.92-1.15)$. A subgroup analysis for menopause status found that although fermented dairy products had no significant effect on the premenopausal population $(\mathrm{HR}=0.98,95 \% \mathrm{CI}=0.94-1.03, p=0.52)$, they had a protective effect on the postmenopausal population $(\mathrm{HR}=$ $0.96,95 \% \mathrm{CI}=0.93-0.99, p=0.021)$ and could reduce $\mathrm{BC}$ risk in the postmenopausal population without heterogeneity $\left(\mathrm{I}^{2}=0 \%\right)$. Table 2 lists the detailed data.

\section{Analysis about the effects of non-fermented dairy products on $\mathrm{BC}$}

Thirteen studies (594,111 participants) explored the effect of non-fermented dairy products on BC risk in 
Table 1 Characteristics of included clinical trials in the meta-analysis

\begin{tabular}{|c|c|c|c|c|c|c|c|}
\hline Author, year & Country & $\begin{array}{l}\text { Age of } \\
\text { recruitment } \\
\text { (year) }\end{array}$ & $\begin{array}{l}\text { Age of } \\
\text { analysis (year) }\end{array}$ & $\begin{array}{l}\text { Follow-up } \\
\text { time (year) }\end{array}$ & $\begin{array}{l}\text { No. of } \\
\text { cases }\end{array}$ & $\begin{array}{l}\text { No. of } \\
\text { participants }\end{array}$ & Characteristics \\
\hline Kaluza, 2020 & Swedish & $48-83$ & $63.6 \pm 9.4$ & 16.6 & 1870 & 33,780 & $\begin{array}{l}\text { The Swedish Mammography } \\
\text { Cohort }\end{array}$ \\
\hline Farvid, 2018 & Amercia & $25-42$ & $37.1 \pm 4.6$ & NA & 4509 & 90,503 & The Nurses' Health Study II cohort \\
\hline Fraser, 2020 & Amercia & $\geq 30$ & $57.1 \pm 3.5$ & 7.9 & 1057 & 25,795 & The Adventist Health Study-2 \\
\hline $\begin{array}{l}\text { Genkinger, } \\
2013\end{array}$ & Amercia & $21-69$ & NA & 12 & 1268 & 59,027 & The Black Women's Health Study \\
\hline $\begin{array}{l}\text { Kesse-Guyot, } \\
2007\end{array}$ & French & $35-60$ & $51.2 \pm 6.3$ & 8 & 92 & 3627 & The French SU.VI.MAX Study \\
\hline Knekt, 1996 & Finland & $15-90$ & $39.1 \pm 16.5$ & 25 & 88 & 4697 & $\begin{array}{l}\text { The Finnish Mobile Clinic Health } \\
\text { Examination Survey }\end{array}$ \\
\hline Shin, 2002 & Amercia & $35-70$ & $46.7 \pm 7.6$ & 16.5 & 3482 & 88,691 & The Nurses'Health Study \\
\hline Pala, 2009 & European & $25-70$ & $50.8 \pm 8.4$ & 8.8 & 7119 & 319,826 & Cancer and Nutrition cohort \\
\hline $\begin{array}{l}\text { Marcondes, } \\
2019\end{array}$ & Netherlands & $\geq 55$ & $68.3 \pm 8.7$ & 17 & 199 & 3092 & The Rotterdam Study \\
\hline Shin, 2019 & Korean & $40-69$ & $52.7 \pm 7.9$ & 6.3 & 359 & 78,320 & The Health Examinees-Gem \\
\hline Hjartåker, 2010 & Norway & $26-64$ & $56.8 \pm 6.7$ & 8.6 & 1407 & 64,904 & $\begin{array}{l}\text { The Norwegian Women and Cancer } \\
\text { study }\end{array}$ \\
\hline $\begin{array}{l}\text { McCullough, } \\
2005\end{array}$ & Amercia & $50-74$ & $62.2 \pm 4.2$ & 9 & 2855 & 97,786 & $\begin{array}{l}\text { The Cancer Prevention Study II } \\
\text { Nutrition Cohort }\end{array}$ \\
\hline Gaard, 1995 & England & $35-49$ & $43.5 \pm 8.4$ & $7-13$ & 248 & 25,892 & $\begin{array}{l}\text { The Norwegian National Health } \\
\text { Screening Services }\end{array}$ \\
\hline Wirfält, 2011 & Sweden & $45-73$ & NA & 10.3 & 544 & 17,035 & The Malmo Diet and Cancer Cohort \\
\hline Yu, 2019 & China & $25-70$ & NA & NA & 1286 & 2747 & NA \\
\hline $\begin{array}{l}\text { Franceschi, } \\
1995\end{array}$ & Italy & $23-74$ & $55.3 \pm 4.3$ & NA & 2569 & 55,175 & NA \\
\hline $\begin{array}{l}\text { Galván-Salazar, } \\
2015\end{array}$ & Mexican & $40-65$ & $50.7 \pm 7.5$ & NA & 97 & 201 & NA \\
\hline $\begin{array}{l}\text { Potischman, } \\
2002\end{array}$ & Amercia & $20-44$ & NA & NA & 568 & 2019 & NA \\
\hline $\begin{array}{l}\text { Jayalekshmi, } \\
2009\end{array}$ & India & $\geq 20$ & $46.4 \pm 3.6$ & NA & 792 & 1056 & NA \\
\hline Hirose, 2003 & Japan & $\geq 30$ & NA & NA & 2385 & 21,398 & NA \\
\hline Bao, 2012 & China & $25-70$ & NA & NA & 3443 & 6917 & The Shanghai Breast Cancer Study \\
\hline $\begin{array}{l}\text { Van 't Veer, } \\
1991\end{array}$ & Netherlands & $25-44,55-64$ & NA & 1.5 & 133 & 422 & NA \\
\hline $\begin{array}{l}\text { Bahadoran, } \\
2013\end{array}$ & Iran & $30-65$ & $46.2 \pm 8.9$ & NA & 100 & 275 & NA \\
\hline Toniolo, 1994 & Amercia & $35-65$ & $52.2 \pm 8.4$ & 22.2 & 180 & 1009 & $\begin{array}{l}\text { The New York University Women's } \\
\text { Health Study }\end{array}$ \\
\hline $\begin{array}{l}\text { Plagens- } \\
\text { Rotman, } 2017\end{array}$ & Poland & $21-84$ & $52.5 \pm 11.1$ & NA & 79 & 762 & NA \\
\hline Lima, 2008 & Brazil & $30-80$ & $56.3 \pm 6.8$ & NA & 89 & 183 & NA \\
\hline Lê, 1986 & French & $40-70$ & NA & NA & 1010 & 2960 & NA \\
\hline Shannon, 2003 & Amercia & $50-64$ & NA & NA & 440 & 810 & NA \\
\hline Kato, 1992 & Japan & $\geq 20$ & NA & NA & 908 & 1816 & NA \\
\hline $\begin{array}{l}\text { Mobarakeh, } \\
2014\end{array}$ & Iran & $20-65$ & $40.2 \pm 10.1$ & NA & 53 & 93 & NA \\
\hline $\begin{array}{l}\text { Potischman, } \\
1998\end{array}$ & Amercia & $\leq 45$ & NA & NA & 1647 & 3148 & NA \\
\hline
\end{tabular}


Table 1 Characteristics of included clinical trials in the meta-analysis (Continued)

\begin{tabular}{|c|c|c|c|c|c|c|c|}
\hline Author, year & Country & $\begin{array}{l}\text { Age of } \\
\text { recruitment } \\
\text { (year) }\end{array}$ & $\begin{array}{l}\text { Age of } \\
\text { analysis (year) }\end{array}$ & $\begin{array}{l}\text { Follow-up } \\
\text { time (year) }\end{array}$ & $\begin{array}{l}\text { No. of } \\
\text { cases }\end{array}$ & $\begin{array}{l}\text { No. of } \\
\text { participants }\end{array}$ & Characteristics \\
\hline McCann, 2017 & Amercia & $35-75$ & $45.5 \pm 5.9$ & NA & 1857 & 3059 & NA \\
\hline Zhang, 2011 & China & $25-70$ & $47.0 \pm 9.5$ & NA & 438 & 876 & NA \\
\hline $\begin{array}{l}\text { van't Veer, } \\
1989\end{array}$ & Netherlands & $25-64$ & NA & NA & 133 & 548 & NA \\
\hline Ronco, 2002 & Uruguay & $\leq 85$ & NA & NA & 111 & 333 & NA \\
\hline $\begin{array}{l}\text { Ahmadnia, } \\
2016\end{array}$ & Iran & $36-50$ & NA & NA & 225 & 450 & NA \\
\hline
\end{tabular}

NA: not available

female populations, six of which included detailed data on different menopausal conditions. A total of 17,145 participants were newly diagnosed with $\mathrm{BC}$ during the study period. The analysis showed that non-fermented dairy products did not affect all populations $(H R=0.99$, $p=0.54)$, including premenopausal $(\mathrm{HR}=1.03, p=0.33)$ and postmenopausal population $(\mathrm{HR}=1.03, p=0.30)$ with low heterogeneity. Table 2 includes the detailed data.
Analysis about the effect of high-fat dairy products on BC In total, 12 studies investigated the relationship between high-fat dairy products and BC. Six studies compared the risk rates between premenopausal and postmenopausal populations. Among 424,176 participants, 19,208 were newly diagnosed with $\mathrm{BC}$. After meta-analysis, no statistically significant difference was observed in the effect of high-fat dairy products on all populations ( $\mathrm{HR}=$ $1.06,95 \% \mathrm{CI}=1.00-1.13, p=0.066)$. However, there was

Table 2 Effects of dairy products on breast cancer incidence

\begin{tabular}{|c|c|c|c|c|c|c|c|}
\hline Subgroup analysis & $\begin{array}{l}\text { No. of } \\
\text { studies }\end{array}$ & Cases & Participants & HR & $95 \% \mathrm{Cl}$ & $p$ & $\begin{array}{l}\text { Heterogeneity } \\
\left(I^{2}\right)(\%)\end{array}$ \\
\hline All populations & 25 & 30,334 & 726,673 & 0.95 & $0.91-0.99$ & 0.019 & 63.2 \\
\hline ER+ breast cancer & 4 & 6466 & 185,355 & 0.79 & $0.68-0.92$ & 0.002 & 66.4 \\
\hline ER- breast cancer & 4 & 6466 & 185,355 & 1.06 & $0.92-1.22$ & 0.42 & 0 \\
\hline PR+ breast cancer & 3 & 3611 & 87,569 & 0.75 & $0.58-0.97$ & 0.027 & 73.9 \\
\hline PR- breast cancer & 3 & 3611 & 87,569 & 1.05 & $0.90-1.21$ & 0.56 & 0 \\
\hline $\mathrm{ER}+/ \mathrm{PR}+$ breast cancer & 5 & 11,563 & 184,989 & 0.92 & $0.85-1.01$ & 0.075 & 73.0 \\
\hline ER-/PR- breast cancer & 5 & 11,563 & 184,989 & 0.96 & $0.88-1.05$ & 0.36 & 32.5 \\
\hline Premenopausal population & 8 & 14,863 & 653,249 & 1.02 & $0.97-1.07$ & 0.37 & 5.9 \\
\hline Postmenopausal population & 8 & 14,863 & 653,249 & 1.00 & $0.97-1.04$ & 0.83 & 0 \\
\hline Fermented dairy products & 14 & 16,280 & 496,747 & 0.98 & $0.95-1.02$ & 0.25 & 41.9 \\
\hline Fermented dairy products for ER+/PR+ breast cancer & 2 & 2414 & 50,815 & 1.01 & $0.97-1.05$ & 0.62 & 12.3 \\
\hline Fermented dairy products for ER-/PR- breast cancer & 2 & 2414 & 50,815 & 1.03 & $0.92-1.15$ & 0.63 & 37.4 \\
\hline Fermented dairy products for the premenopausal population & 6 & 14,425 & 561,870 & 0.98 & $0.94-1.03$ & 0.52 & 0 \\
\hline Fermented dairy products for the postmenopausal population & 6 & 14,425 & 561,870 & 0.96 & $0.93-0.99$ & 0.021 & 0 \\
\hline Non-fermented dairy products & 13 & 17,145 & 594,111 & 0.99 & $0.94-1.03$ & 0.54 & 0 \\
\hline Non-fermented dairy products for the premenopausal population & 6 & 14,425 & 561,870 & 1.03 & $0.97-1.09$ & 0.33 & 0 \\
\hline Non-fermented dairy products for the postmenopausal population & 6 & 14,425 & 561,870 & 1.03 & $0.98-1.08$ & 0.30 & 20.2 \\
\hline High fat dairy products & 12 & 19,208 & 624,176 & 1.06 & $1.00-1.13$ & 0.066 & 63.7 \\
\hline High fat dairy products for premenopausal populations & 6 & 17,873 & 584,718 & 1.01 & $0.96-1.07$ & 0.61 & 0 \\
\hline High fat dairy products for the postmenopausal population & 6 & 17,873 & 584,718 & 1.00 & $0.95-1.04$ & 0.87 & 0 \\
\hline Low fat dairy products & 11 & 19,699 & 615,226 & 0.98 & $0.94-1.03$ & 0.50 & 63.1 \\
\hline Low fat dairy products for the premenopausal population & 6 & 17,873 & 584,718 & 0.94 & $0.89-1.00$ & 0.048 & 33.5 \\
\hline Low fat dairy products for the postmenopausal population & 6 & 17,873 & 584,718 & 1.04 & $0.99-1.09$ & 0.15 & 22.6 \\
\hline
\end{tabular}

HR: hazard ratio; Cl: confidence interval; ER: estrogen receptor; PR: progesterone receptor 
a harm trend, indicating that high-fat dairy product consumption tends to increase BC risk in female populations, with moderate heterogeneity $\left(\mathrm{I}^{2}=63.7 \%\right)$. Apart from that, the analysis also revealed that high-fat dairy products did not affect premenopausal $(\mathrm{HR}=1.01, p=$ 0.61 ) and postmenopausal populations ( $\mathrm{HR}=1.00, p=$ $0.87)$. The heterogeneity between different studies was all $0 \%$. Table 2 comprises the detailed data.

\section{Analysis about the effect of low-fat dairy products on BC} Eleven studies (615,226 participants) explored the impact of low-fat dairy products on $\mathrm{BC}$, including six studies $(584,718$ participants) grouped by menopause. During the study period, During the study period, 19,699 newly detected BC cases were found. According to the meta-analysis, low-fat dairy products were found to have no noticeable effect on all populations $(\mathrm{HR}=$ $0.98,95 \% \mathrm{CI}=0.94-1.03, p=0.50$ ) and postmenopausal population $(\mathrm{HR}=1.04,95 \% \mathrm{CI}=0.99-1.09, \quad p=0.15)$. However, for the premenopausal population, the consumption of low-fat dairy products conferred a statistically significant difference in protection against $\mathrm{BC}$ $(\mathrm{HR}=0.94,95 \% \mathrm{CI}=0.89-1.00, p=0.048)$ with moderate heterogeneity among studies $\left(\mathrm{I}^{2}=22.6 \%\right)$. Table 2 provides the detailed data.

\section{Risk of bias assessment}

The NOS checklist was adopted to objectively evaluate the quality of included observational studies in this meta-study. According to the quality evaluation results of the investigators, 13 studies out of 36 were rated 9 points, 16 studies were rated 8 points, 5 studies were rated 7 points and 2 studies were rated 6 points. All included studies were of higher quality based on methodology. Supplementary Table 2 explicitly recorded the assessment of risk of bias.

\section{Analysis of publication bias and sensitivity}

Begg's rank correlation and Egger's linear regression test were employed to estimate publication bias. Begg's rank correlation test and Egger's linear regression test results indicated the absence of publication bias among included articles $(p>0.05)$. The sensitivity analysis suggested that the overall risk assessment was not substantially modified by any single study, revealing the stability of the above results.

\section{Discussion}

Whether dairy products play a protective or harmful role against $\mathrm{BC}$ occurrence in female population is still controversial. Review of previous studies, Zang J et al. [87] also conducted a meta-analysis of the relationship between BC and dairy products, but their study did not conduct multifactorial subgroup analysis. In addition, their study considered cheese and butter as the same exposure factor and yogurt as another exposure factor. However, since cheese and yogurt are fermented dairy products and butter is not, they did not analyze fermented dairy products as a whole and misclassified cheese and butter, implying that the result could lack reliability. There was also inadequacy in the meta-analysis of Dong JY et al. [88] First, their studies were only retrieved from PubMed one database, probably ignoring the potentially included studies. Second, they only performed a subgroup analysis on the role of milk and could not provide a comprehensive conclusion.

Compared with previous studies, our study has its own strengths. First, this study included many observational studies with more than one million participants in Asia, Europe, and the Americas. The larger observational population increases the reliability and authenticity of this study's conclusions. Secondly, this study selected HR data that adjusted the largest number of potential confounding factors for statistical analysis to improve accuracy. Third, the study grouped the abstracted data (by BC type, menopausal status, or type of dairy products) and did subgroup analyses to comprehensively screen the possibility of effects of different dairy products on different populations and different $\mathrm{BC}$ types.

According to data analysis, we found that total dairy products have a protective effect on female populations, which can reduce the incidence rate of $\mathrm{BC}$, especially $\mathrm{ER}+$ and $\mathrm{PR}+\mathrm{BC}$. For $\mathrm{ER}+/ \mathrm{PR}+\mathrm{BC}$, there is a trend of protection without reaching a statistical significance. Fermented dairy products can reduce BC risk in postmenopausal population but have no protective effect on premenopausal population. Nonfermented dairy products have no significant effect on $\mathrm{BC}$ occurrence. There is a trend towards harm in the female population with high-fat dairy products. Although a statistically significant difference was not reached, it is suggested that excess high-fat dairy intake may elevate $\mathrm{BC}$ incidence. In contrast, low-fat dairy products can protect the premenopausal population and reduce the incidence rate of $\mathrm{BC}$.

Because of their complex composition, no clear mechanism of action has been proposed to explain the contribution of dairy products to $\mathrm{BC}$ incidence [17]. Recent works have shown that dairy products have both pro- and anti-carcinogenic effects. Dairy products are rich in calcium, vitamin $\mathrm{D}$, and conjugated linoleic acid (CLA), which affect cell proliferation and differentiation and can inhibit tumor development [89-92]. Conversely, large amounts of fats, saturated fats, and potentially carcinogenic contaminants (pesticides, estrogen metabolites, and growth factors including insulin-like growth factors-1 (IGF-1)) in dairy products increase BC risk $[89,93,94]$. 
Dairy calcium can have antiproliferative properties by reducing the ability of circulating lipids to induce cell proliferation [92, 95, 96]. Vitamin D was shown to interrupt insulin and IGF-1 and reduce carcinogenesis [97, 98]. Insulin stimulates the elevation of free IGF-1, which can promote cell cycle progression and angiogenesis and has anti-apoptotic properties $[43,79,99]$. CLA is a mixture of positional and geometric isomers of linoleic acid, which are mainly from dairy products $(60 \%)$ and beef products (32\%) [100]. It has anticancer effect in animal experiments and is an effective anticancer drug with cytotoxic effects on BC cells [82, 101], potentially by inhibiting the cyclooxygenase- 2 or lipoxygenase pathways or by inducing the expression of apoptotic genes $[80,102]$. Accordingly, we speculate that dairy products may have a protective effect on female populations through many of the above pathways to reduce the risk rate of $\mathrm{BC}$. In addition to these, studies have shown that dairy partial ingredients and their bioactive components can exert inhibitory effects on BC by downregulating ER- $\alpha$ expression and activity, inhibiting proliferation, metastasis, and angiogenesis of breast tumor cells, inducing apoptosis and cell cycle arrest and sensitizing breast tumor cells to radiotherapy and chemotherapy, which may explain the reason why dairy products have apparent protective effects on hormone receptor-positive $\mathrm{BC}$ [33, 103-105].

Fermented dairy products, such as yogurt and cheese, have a superior nutritional value over non-fermented milk due to their high concentrations in beneficial bacteria, calcium, riboflavin, vitamin B6, and vitamin B12 [106]. Studies have shown that the probiotic Lactobacillus acidophilus, present in yogurt, modulates immune responses against BC in mouse models [107]. By increasing age, the gut exhibits declining levels of bifidobacteria with antitumor effects, which allow toxin-induced tumor growth producing bacteria to thrive, such that postmenopausal populations have lower levels of intestinal probiotics than premenopausal populations [108]. Whereas fermented dairy products can provide probiotics to supplement and balance the gut microbial community, thereby reducing cancer risk [109]. In addition, IGF-I amount that may increase BC risk is significantly reduced in processed heat-treated or fermented dairy products $[87,110]$. Combined with the above mechanisms, it may help explain that consumption of fermented dairy products can reduce $\mathrm{BC}$ incidence in postmenopausal population. Similarly, non-fermented dairy products that lack probiotics cannot balance the intestinal microbial community and may not affect $\mathrm{BC}$ occurrence.

Two potential reasons exist for the detrimental effect of high-fat dairy products on female BC. The first explanation is that high-fat dairy products directly induce
$\mathrm{BC}$ [111]. Animal experiments have found that a highfat diet increases mammary epithelial cell proliferation, particularly "hormonally driven" hyperproliferation during mammary gland outgrowth and development in young animals, enhancing the promotion of chemically induced mammary carcinogenesis and increasing $\mathrm{BC}$ risk in adulthood [96, 112]. The second explanation is that consuming high-fat dairy products leads to obesity and type 2 diabetes mellitus (T2D), thus increasing the risk of cancer. In particular, $\mathrm{BC}$ is more strongly associated with obesity than other cancers $[113,114]$. Obese people also have metabolic syndrome, which increases their risk of T2D. Obesity and T2D result in hyperinsulinemia $[115,116]$, increased insulin-like growth factor [117, 118], hyperglycemia [119], dyslipidemia [120, 121], increased adipokines [122], increased inflammatory cytokines [123] and changes in intestinal microorganisms $[124,125]$, which may increase the risk of cancer through various mechanisms.

Although consuming fats increases BC risk [126, 127], the effect of different types of fatty acids on $\mathrm{BC}$ varies, with studies suggesting that saturated fatty acids are associated with increased BC risk. However, no clear association between total, monounsaturated, or polyunsaturated fatty acids and $\mathrm{BC}$ has been observed [128, 129]. Whereas low-fat dairy products differ from high-fat dairy products in the amount of fatty acids obtained by refining full-fat dairy products to extract most saturated fatty acids while preserving unsaturated fatty acids [87]. In addition to this, studies have demonstrated that the association between dairy intake and $\mathrm{BC}$ risk is stronger in premenopausal women than in postmenopausal women $[43,79,130]$, possibly caused by more robust interactions between calcium, vitamin D, and IGF-1 than in postmenopause [130-132]. This may explain why low-fat dairy products appear to have a risklowering impact in the premenopausal population but have no apparent effect in the postmenopausal population.

Although this meta-analysis reached comprehensive and objective conclusions, there are still potential limitations that need to be considered. First, all risk estimates of included studies used multivariate models, but potential risk factors were not adjusted in the same way between studies. Therefore, we cannot exclude the possibility that inadequate control of potential risk confounders contributed to biased results. Second, most studies assessed diet using self-reported FFQs based on their plausibility and reproducibility, although a few used interviews, implying that dietary assessment inevitably produces assessment or measurement error, most likely biasing the findings. Third, consideration should be given to classification biases in dairy products. Because dietary assessments across studies were conducted based 
on different databases and different FFQs, there may be inconsistencies in the conclusions resulting from different methods of classifying dairy products. Fourth, there may be significant heterogeneity among the included studies due to reported population variations in terms of lifestyle preferences, living locations, and so on. Fifth, not all trials had accessible relevant subgroup data, such as subgroup data by BC type, subgroup data by menopausal status, and thus large-scale observational studies are still required to further validate the relevant conclusions.

Overall, this meta-analysis leads to meaningful conclusions that may allow new recommendations on $\mathrm{BC}$ prevention in female populations. Based on the results of this study, we recommend that women should be well suited to consume some dairy products, especially recommending low-fat dairy products for premenopausal women and fermented dairy products for postmenopausal women, minimizing the intake of high-fat dairy products, which may help to reduce the risk of $\mathrm{BC}$.

\section{Conclusion}

This meta-analysis found that total dairy products could reduce $B C$ risk in female populations, especially $E R+B C$ and $\mathrm{PR}+\mathrm{BC}$. There was a trend toward protection for $\mathrm{ER}+/ \mathrm{PR}+\mathrm{BC}$ that was not statistically significant. In addition, fermented dairy products can reduce $\mathrm{BC}$ risk in postmenopausal population, and low-fat dairy products can reduce $\mathrm{BC}$ risk in premenopausal population. However, high-fat dairy products are harmful to female population, without statistically significant difference. Based on considerations of relevant limitations, largescale prospective cohort studies are still required to further confirm the study conclusions.

\begin{abstract}
Abbreviations
BC: breast cancer; ER: estrogen receptor; PR: progesterone receptor; MOOSE: the meta-analysis of observational studies in epidemiology PICOS: the population, intervention, comparison, outcome and setting criteria; HR: hazard ratio; Cl: confidence interval; NOS: the Newcastle-Ottawa quality assessment scale checklist; BMI: body mass index; HRT: hormone replacement therapy; FFQ: food frequency questionnaire; CLA: conjugated linoleic acid; IGF-1: insulin-like growth factors-1; T2D: type 2 diabetes mellitus.
\end{abstract}

\section{Supplementary Information}

The online version contains supplementary material available at https://doi. org/10.1186/s12885-021-08854-w.

Additional file $\mathbf{1}$ Supplementary Table $\mathbf{1}$ Characteristics of included

clinical trials in the meta-analysis.

Additional file $\mathbf{2}$ Supplementary Table $\mathbf{2}$ Quality assessment of studies included.

Acknowledgments

Not applicable.

Consent to publish

Not applicable.
Authors' contributions

All authors helped to perform the research. Yujing He, Qinghua Tao, and Bangsheng Chen manuscript writing; Feifei Zhou and Yuexiu Si performing procedures and data analysis; Rongrong Fu, Binbin Xu and Jiaxuan Xu contribution to writing the manuscript; Xiangyuan Li contribution to drafting conception and design.

\section{Funding}

The authors received no financial support in conducting this meta-analysis.

\section{Availability of data and materials}

Data supporting findings reported in this study are available in the supplementary materials.

\section{Declarations}

Ethics approval and consent to participate

Not applicable.

\section{Competing interests}

The authors declare no conflict of interest.

\section{Author details}

${ }^{1}$ The Second Clinical Medical College, Zhejiang Chinese Medical University, Zhejiang, Hangzhou, China. ${ }^{2}$ Emergency Medical Center, Ningbo Yinzhou No. 2 Hospital, Ningbo, Zhejiang, China. ${ }^{3}$ School of Basic Medical Sciences, Zhejiang Chinese Medical University, Zhejiang, Hangzhou, China. ${ }^{4}$ The First Clinical Medical College, Zhejiang Chinese Medical University, Zhejiang, Hangzhou, China. ${ }^{5}$ Department of Nutrition, HwaMei Hospital, University of Chinese Academy of Sciences, Ningbo, Zhejiang, China.

Received: 21 May 2021 Accepted: 8 October 2021

Published online: 15 October 2021

\section{References}

1. Akram M, lqbal M, Daniyal M, Khan AU. Awareness and current knowledge of breast cancer. Biol Res. 2017;50(1):33. https://doi.org/10.1186/s40659-0170140-9.

2. Bonofiglio D, Giordano C, de Amicis F, Lanzino M, Andò S. Natural products as promising Antitumoral agents in breast Cancer: mechanisms of action and molecular targets. Mini Rev Med Chem. 2016;16(8):596-604. https://doi. org/10.2174/1389557515666150709110959.

3. Sun YS, Zhao Z, Yang ZN, Xu F, Lu HJ, Zhu ZY, et al. Risk factors and preventions of breast Cancer. Int J Biol Sci. 2017;13(11):1387-97. https://doi. org/10.7150/ijbs.21635

4. Winters $S$, et al. Breast Cancer epidemiology, Prevention, and screening. Prog Mol Biol Transl Sci. 2017;151:1-32. https://doi.org/10.1016/bs.pmbts.201 7.07.002.

5. Sung $H$, Ferlay J, Siegel RL, Laversanne $M$, Soerjomataram I, Jemal $A$, et al. Global cancer statistics 2020: GLOBOCAN estimates of incidence and mortality worldwide for 36 cancers in 185 countries. CA Cancer J Clin. 2021; 71(3):209-49. https://doi.org/10.3322/caac.21660.

6. Bray F, Ferlay J, Soerjomataram I, Siegel RL, Torre LA, Jemal A. Global cancer statistics 2018: GLOBOCAN estimates of incidence and mortality worldwide for 36 cancers in 185 countries. CA Cancer J Clin. 2018:68(6):394-424. https://doi.org/10.3322/caac.21492.

7. Fidler MM, Gupta S, Soerjomataram I, Ferlay J, Steliarova-Foucher E, Bray F. Cancer incidence and mortality among young adults aged $20-39$ years worldwide in 2012: a population-based study. Lancet Oncol. 2017;18(12): 1579-89. https://doi.org/10.1016/S1470-2045(17)30677-0.

8. Zeng L, Li W, Chen CS. Breast cancer animal models and applications. Zool Res. 2020;41(5):477-94. https://doi.org/10.24272/j.issn.2095-8137.2020.095.

9. Lee A, Moon BI, Kim TH. BRCA1/BRCA2 pathogenic variant breast Cancer: treatment and Prevention strategies. Ann Lab Med. 2020;40(2):114-21. https://doi.org/10.3343/alm.2020.40.2.114.

10. Kwong A, Shin WY, Ho JCW, Kang E, Nakamura S, Teo SH, et al. Comprehensive spectrum of BRCA1 and BRCA2 deleterious mutations in breast cancer in Asian countries. J Med Genet. 2016;53(1):15-23. https://doi. org/10.1136/jmedgenet-2015-103132.

11. Jia Y, Lu Y, Wu K, Lin Q, Shen W, Zhu M, et al. Does night work increase the risk of breast cancer? A systematic review and meta-analysis of 
epidemiological studies. Cancer Epidemiol. 2013;37(3):197-206. https://doi. org/10.1016/j.canep.2013.01.005.

12. Park SY, Kolonel LN, Lim U, White KK, Henderson BE, Wilkens LR. Alcohol consumption and breast cancer risk among women from five ethnic groups with light to moderate intakes: the multiethnic cohort study. Int I Cancer. 2014;134(6):1504-10. https://doi.org/10.1002/ijc.28476.

13. Rieder $\mathrm{V}$, et al. Effect of lifestyle and reproductive factors on the onset of breast cancer in female BRCA 1 and 2 mutation carriers. Mol Genet Genomic Med. 2016;4(2):172-7.

14. Zbuk K, Anand SS. Declining incidence of breast cancer after decreased use of hormone-replacement therapy: magnitude and time lags in different countries. J Epidemiol Community Health. 2012;66(1):1-7. https://doi.org/1 0.1136/jech.2008.083774.

15. Youn HJ, Han W. A review of the epidemiology of breast Cancer in Asia: focus on Risk factors. Asian Pac J Cancer Prev. 2020;21(4):867-80.

16. Barzaman K, Karami J, Zarei Z, Hosseinzadeh A, Kazemi MH, Moradi-Kalbolandi S, et al. Breast cancer: biology, biomarkers, and treatments. Int Immunopharmacol. 2020;84:106535. https://doi.org/10.1016/j.intimp.2020.106535.

17. Li Y, Li S, Meng X, Gan RY, Zhang JJ, Li HB. Dietary Natural Products for Prevention and Treatment of Breast Cancer. Nutrients. 2017;9(7):9(7). https:// doi.org/10.3390/nu9070728.

18. Mourouti N, Kontogianni MD, Papavagelis C, Panagiotakos DB. Diet and breast cancer: a systematic review. Int J Food Sci Nutr. 2015;66(1):1-42. https://doi.org/10.3109/09637486.2014.950207.

19. Nagini S. Breast Cancer: current molecular therapeutic targets and new players. Anti Cancer Agents Med Chem. 2017;17(2):152-63.

20. Hadadi E, Taylor W, Li XM, Aslan Y, Villote M, Rivière J, et al. Chronic circadian disruption modulates breast cancer stemness and immune microenvironment to drive metastasis in mice. Nat Commun. 2020;11(1): 3193. https://doi.org/10.1038/s41467-020-16890-6.

21. Godinho-Mota, J.C.M., et al., Sedentary Behavior and Alcohol Consumption Increase Breast Cancer Risk Regardless of Menopausal Status: A Case-Control Study. Nutrients, 2019. 11(8), Sedentary Behavior and Alcohol Consumption Increase Breast Cancer Risk Regardless of Menopausal Status: A Case-Control Study, 11, 8, doi: https://doi.org/10.3390/nu11081871.

22. Sun $\mathrm{Q}$, Xie W, Wang Y, Chong F, Song M, Li T, et al. Alcohol consumption by beverage type and Risk of breast Cancer: a dose-response Meta-analysis of prospective cohort studies. Alcohol Alcohol. 2020;55(3):246-53. https:// doi.org/10.1093/alcalc/agaa012.

23. Duan W, Li S, Meng X, Sun Y, Jia C. Smoking and survival of breast cancer patients: a meta-analysis of cohort studies. Breast. 2017;33:117-24. https:// doi.org/10.1016/j.breast.2017.03.012.

24. Fraser GE, Jaceldo-Siegl K, Orlich M, Mashchak A, Sirirat R, Knutsen S. Dairy, soy, and risk of breast cancer: those confounded milks. Int J Epidemiol. 2020;49(5):1526-37. https://doi.org/10.1093/ije/dyaa007.

25. Andersen JLM, et al. Pre- and post-diagnostic intake of whole grain and dairy products and breast cancer prognosis: the Danish Diet, Cancer and health cohort. Breast Cancer Res Treat. 2020;179(3):743-53.

26. Schwingshackl L, Schwedhelm C, Hoffmann G, Knüppel S, lqbal K, Andriolo $V$, et al. Food groups and Risk of hypertension: a systematic review and dose-response Meta-analysis of prospective studies. Adv Nutr. 2017;8(6):793803. https://doi.org/10.3945/an.117.017178.

27. Dandamudi A, et al. Dietary patterns and breast Cancer Risk: a systematic review. Anticancer Res. 2018:38(6):3209-22. https://doi.org/10.21873/anticanres.12586.

28. Rigi S, Mousavi SM, Benisi-Kohansal S, Azadbakht L, Esmaillzadeh A. The association between plant-based dietary patterns and risk of breast cancer: a case-control study. Sci Rep. 2021;11(1):3391. https://doi.org/10.1038/s41 598-021-82659-6.

29. Chlebowski RT, Aragaki AK, Anderson GL, Thomson CA, Manson JAE, Simon MS, et al. Low-fat dietary pattern and breast Cancer mortality in the Women's Health Initiative randomized controlled trial. J Clin Oncol. 2017; 35(25):2919-26. https://doi.org/10.1200/JCO.2016.72.0326.

30. Krusinska B, et al. Dietary patterns and breast or lung cancer risk: a pooled analysis of 2 case-control studies in North-Eastern Poland. Adv Clin Exp Med. 2017;26(9):1367-75. https://doi.org/10.17219/acem/65433.

31. Turati, F., et al., Mediterranean Diet and Breast Cancer Risk. Nutrients, 2018. 10(3), Mediterranean Diet and Breast Cancer Risk, 10, 3, doi: https://doi.org/1 0.3390/nu10030326.

32. Albuquerque RC, Baltar VT, Marchioni DM. Breast cancer and dietary patterns: a systematic review. Nutr Rev. 2014;72(1):1-17. https://doi.org/1 $0.1111 /$ nure. 12083
33. Varinska L, Gal P, Mojzisova G, Mirossay L, Mojzis J. Soy and breast cancer: focus on angiogenesis. Int J Mol Sci. 2015;16(5):11728-49. https://doi.org/1 0.3390/ijms 160511728 .

34. Hanf $\mathrm{V}$, Gonder $\mathrm{U}$. Nutrition and primary prevention of breast cancer: foods, nutrients and breast cancer risk. Eur J Obstet Gynecol Reprod Biol. 2005; 123(2):139-49. https://doi.org/10.1016/j.ejogrb.2005.05.011.

35. Gandini S, Merzenich H, Robertson C, Boyle P. Meta-analysis of studies on breast cancer risk and diet: the role of fruit and vegetable consumption and the intake of associated micronutrients. Eur J Cancer. 2000;36(5):636-46. https://doi.org/10.1016/S0959-8049(00)00022-8.

36. Chen $S$, Chen $Y$, Ma S, Zheng R, Zhao P, Zhang L, et al. Dietary fibre intake and risk of breast cancer: a systematic review and meta-analysis of epidemiological studies. Oncotarget. 2016;7(49):80980-9. https://doi.org/10.1 8632/oncotarget.13140.

37. Buja, A., et al., Breast Cancer Primary Prevention and Diet: An Umbrella Review. Int J Environ Res Public Health, 2020. 17(13), Breast Cancer Primary Prevention and Diet: An Umbrella Review, 17, 13, doi: https://doi.org/10.33 90/ijerph17134731.

38. Hjartaker A, Laake P, Lund E. Childhood and adult milk consumption and risk of premenopausal breast cancer in a cohort of 48,844 women - the Norwegian women and cancer study. Int J Cancer. 2001;93(6):888-93. https://doi.org/10.1002/ijc.1409.

39. Hjartaker $\mathrm{A}$, et al. Dairy consumption and calcium intake and risk of breast cancer in a prospective cohort: the Norwegian women and Cancer study. Cancer Causes Control. 2010;21(11):1875-85. https://doi.org/10.1007/s10552-010-9615-5.

40. McCullough ML, et al. Dairy, calcium, and vitamin D intake and postmenopausal breast cancer risk in the Cancer Prevention study II nutrition cohort. Cancer Epidemiol Biomark Prev. 2005;14(12):2898-904. https://doi.org/10.1158/1055-9965.EPI-05-0611.

41. Pala V, et al. Meat, eggs, dairy products, and risk of breast cancer in the European prospective investigation into Cancer and nutrition (EPIC) cohort. Am J Clin Nutr. 2009;90(3):602-12.

42. Kato I, Miura S, Kasumi F, Iwase T, Tashiro H, Fujita Y, et al. A case-control study of breast cancer among Japanese women: with special reference to family history and reproductive and dietary factors. Breast Cancer Res Treat. 1992;24(1):51-9. https://doi.org/10.1007/BF01832358.

43. Kesse-Guyot E, Bertrais S, Duperray B, Arnault N, Bar-Hen A, Galan P, et al. Dairy products, calcium and the risk of breast cancer: results of the French SU.VI.MAX prospective study. Ann Nutr Metab. 2007;51(2):139-45. https:// doi.org/10.1159/000103274.

44. Kaluza J, Komatsu S, Lauriola M, Harris HR, Bergkvist L, Michaëlsson K, et al. Long-term consumption of non-fermented and fermented dairy products and risk of breast cancer by estrogen receptor status - population-based prospective cohort study. Clin Nutr. 2021;40(4):1966-73. https://doi.org/10.1 016/j.clnu.2020.09.013.

45. Ronco AL, De Stefani E, Dattoli R. Dairy foods and risk of breast cancer: a case-control study in Montevideo. Uruguay Eur J Cancer Prev. 2002;11(5): 457-63. https://doi.org/10.1097/00008469-200210000-00008.

46. Lu W, Chen H, Niu Y, Wu H, Xia D, Wu Y. Dairy products intake and cancer mortality risk: a meta-analysis of 11 population-based cohort studies. Nutr J. 2016;15(1):91. https://doi.org/10.1186/s12937-016-0210-9.

47. O'Sullivan TA, et al. Dairy product consumption, dietary nutrient and energy density and associations with obesity in Australian adolescents. J Hum Nutr Diet. 2015;28(5):452-64.

48. O'Connor $L M$, et al. Dietary dairy product intake and incident type 2 diabetes: a prospective study using dietary data from a 7-day food diary. Diabetologia. 2014;57(5):909-17.

49. Zong G, Sun Q, Yu D, Zhu J, Sun L, Ye X, et al. Dairy consumption, type 2 diabetes, and changes in cardiometabolic traits: a prospective cohort study of middle-aged and older Chinese in Beijing and Shanghai. Diabetes Care. 2014;37(1):56-63. https://doi.org/10.2337/dc13-0975.

50. Faber MT, Jensen A, Søgaard M, Høgdall E, Høgdall C, Blaakær J, et al. Use of dairy products, lactose, and calcium and risk of ovarian cancer - results from a Danish case-control study. Acta Oncol. 2012;51(4):454-64. https://doi. org/10.3109/0284186X.2011.636754

51. Dalmeijer GW, Struijk EA, van der Schouw YT, Soedamah-Muthu SS, Verschuren WMM, Boer JMA, et al. Dairy intake and coronary heart disease or stroke--a population-based cohort study. Int J Cardiol. 2013;167(3):925-9. https://doi.org/10.1016/j.ijcard.2012.03.094.

52. Praagman J, Franco OH, Ikram MA, Soedamah-Muthu SS, Engberink MF, van Rooij FJA, et al. Dairy products and the risk of stroke and coronary heart 
disease: the Rotterdam study. Eur J Nutr. 2015;54(6):981-90. https://doi.org/1 0.1007/s00394-014-0774-0.

53. Stroup DF, Berlin JA, Morton SC, Olkin I, Williamson GD, Rennie D, et al. Meta-analysis of observational studies in epidemiology: a proposal for reporting. Meta-analysis of observational studies in epidemiology (MOOSE) group. JAMA. 2000;283(15):2008-12. https://doi.org/10.1001/jama.283.15.2 008.

54. Higgins JP, et al. Measuring inconsistency in meta-analyses. BMJ. 2003; 327(7414):557-60.

55. Gu L, et al. A meta-analysis of the medium- and long-term effects of laparoscopic sleeve gastrectomy and laparoscopic roux-en-Y gastric bypass. BMC Surg. 2020;20(1):30.

56. Li S, et al. A meta-analysis of comparison of proximal gastrectomy with double-tract reconstruction and total gastrectomy for proximal early gastric cancer. BMC Surg. 2019;19(1):117.

57. Wu Z, Gong Y, Wang C, Lin J, Zhao J. Association between salivary s-IgA concentration and dental caries: a systematic review and meta-analysis. Biosci Rep. 2020;40(12). https://doi.org/10.1042/BSR20203208.

58. He XJ, Dai RX, Hu CL. Maternal prepregnancy overweight and obesity and the risk of preeclampsia: a meta-analysis of cohort studies. Obes Res Clin Pract. 2020;14(1):27-33. https://doi.org/10.1016/j.orcp.2020.01.004.

59. Ahmadnia Z, Joukar F, Hasavari F, Roushan ZA, Khalili M. Dietary patterns and Risk of breast Cancer in women in Guilan Province. Iran Asian Pac J Cancer Prev. 2016;17(4):2035-40. https://doi.org/10.7314/APJCP.2016.17.4.203 5.

60. Bahadoran Z, Karimi Z, Houshiar-rad A, Mirzayi HR, Rashidkhani B. Is dairy intake associated to breast cancer? A case control study of Iranian women Nutr Cancer. 2013;65(8):1164-70. https://doi.org/10.1080/01635581.2013.82 8083.

61. Bao PP, et al. Fruit, vegetable, and animal food intake and breast cancer risk by hormone receptor status. Nutr Cancer. 2012;64(6):806-19.

62. Farvid MS, Eliassen AH, Cho E, Chen WY, Willett WC. Dairy consumption in adolescence and early adulthood and Risk of breast Cancer. Cancer Epidemiol Biomark Prev. 2018;27(5):575-84. https://doi.org/10.1158/10559965.EPI-17-0345.

63. Franceschi S, et al. Influence of food groups and food diversity on breast cancer risk in Italy. Int J Cancer. 1995;63(6):785-9.

64. Gaard M, Tretli S, Loken EB. Dietary fat and the risk of breast cancer: a prospective study of 25,892 Norwegian women. Int J Cancer. 1995;63(1):137. https://doi.org/10.1002/ijc.2910630104.

65. Galvan-Salazar HR, et al. Association of Milk and Meat Consumption with the development of breast Cancer in a Western Mexican population. Breast Care (Basel). 2015;10(6):393-6. https://doi.org/10.1159/000442230.

66. Genkinger JM, Makambi KH, Palmer JR, Rosenberg L, Adams-Campbell LL. Consumption of dairy and meat in relation to breast cancer risk in the black Women's health study. Cancer Causes Control. 2013;24(4):675-84. https:// doi.org/10.1007/s10552-013-0146-8.

67. Hirose K, Takezaki T, Hamajima N, Miura S, Tajima K. Dietary factors protective against breast cancer in Japanese premenopausal and postmenopausal women. Int J Cancer. 2003;107(2):276-82. https://doi.org/ 0.1002/ijc. 11373

68. Jayalekshmi P, Varughese SC, Kalavathi, Nair MK, Jayaprakash V, Gangadharan P, et al. A nested case-control study of female breast cancer in Karunagappally cohort in Kerala. India Asian Pac J Cancer Prev. 2009;10(2): 241-6.

69. Knekt $\mathrm{P}$, et al. Intake of dairy products and the risk of breast cancer. $\mathrm{Br} J$ Cancer. 1996;73(5):687-91.

70. Le MG, et al. Consumption of dairy produce and alcohol in a case-control study of breast cancer. J Natl Cancer Inst. 1986;77(3):633-6. https://doi.org/1 0.1093/jnci/77.3.633

71. Lima FE, et al. Diet and cancer in Northeast Brazil: evaluation of eating habits and food group consumption in relation to breast cancer. Cad Saude Publica. 2008;24(4):820-8. https://doi.org/10.1590/S0102-311X20080004 00012.

72. Marcondes $L H$, et al. Animal foods and postmenopausal breast cancer risk: a prospective cohort study. Br J Nutr. 2019;122(5):583-91.

73. McCann SE, Hays J, Baumgart CW, Weiss EH, Yao S, Ambrosone CB. Usual consumption of specific dairy foods is associated with breast Cancer in the Roswell Park Cancer Institute data Bank and BioRepository. Curr Dev Nutr. 2017;1(3):e000422. https://doi.org/10.3945/cdn.117.000422.
74. Mobarakeh ZS, Mirzaei K, Hatmi N, Ebrahimi M, Dabiran S, Sotoudeh G. Dietary habits contributing to breast cancer risk among Iranian women. Asian Pac J Cancer Prev. 2014;15(21):9543-7. https://doi.org/10.7314/APJCP.2 014.15.21.9543.

75. Plagens-Rotman K, Piskorz-Szymendera M, Chmaj-Wierzychowska K, Pieta B. Breast cancer - analysis of the selected risk factors. Eur J Gynaecol Oncol. 2017;38(3):425-30

76. Potischman N, Coates RJ, Swanson CA, Carroll RJ, Daling JR, Brogan DR, et al. Increased risk of early-stage breast cancer related to consumption of sweet foods among women less than age 45 in the United States. Cancer Causes Control. 2002;13(10):937-46. https://doi.org/10.1023/A:10219194161 01.

77. Potischman N, Swanson CA, Hoover RN, Brinton LA, Weiss HA, Coates RJ, et al. Diet during adolescence and risk of breast cancer among young women. J Natl Cancer Inst. 1998;90(3):226-33. https://doi.org/10.1093/jnci/ 90.3.226.

78. Shannon J, Cook LS, Stanford JL. Dietary intake and risk of postmenopausal breast cancer (United States). Cancer Causes Control. 2003;14(1):19-27. https://doi.org/10.1023/A:1022506507984.

79. Shin MH, et al. Intake of dairy products, calcium, and vitamin $d$ and risk of breast cancer. J Natl Cancer Inst. 2002:94(17):1301-11. https://doi.org/10.1 093/jnci/94.17.1301.

80. Shin WK, et al. Milk Consumption Decreases Risk for Breast Cancer in Korean Women under 50 Years of Age: Results from the Health Examinees Study. Nutrients. 2019;12(1).

81. Toniolo P, et al. Consumption of meat, animal products, protein, and fat and risk of breast cancer: a prospective cohort study in New York. Epidemiology. 1994;5(4):391-7.

82. Van't Veer $\mathrm{P}$, et al. Combination of dietary factors in relation to breastcancer occurrence. Int J Cancer. 1991;47(5):649-53.

83. van't Veer $\mathrm{P}$, et al. Consumption of fermented milk products and breast cancer: a case-control study in the Netherlands. Cancer Res. 1989;49(14): 4020-3.

84. Wirfalt $E$, et al. Food sources of fat and sex hormone receptor status of invasive breast tumors in women of the Malmo Diet and Cancer cohort. Nutr Cancer. 2011;63(5):722-33. https://doi.org/10.1080/01635581.2011. 570897.

85. Yu L, Liu L, Wang F, Zhou F, Xiang Y, Huang $S$, et al. Higher frequency of dairy intake is associated with a reduced risk of breast cancer: results from a case-control study in northern and eastern China. Oncol Lett. 2019;17(3): 2737-44. https://doi.org/10.3892/ol.2019.9898.

86. Zhang CX, Ho SC, Fu JH, Cheng SZ, Chen YM, Lin FY. Dairy products, calcium intake, and breast cancer risk: a case-control study in China. Nutr Cancer. 2011;63(1):12-20. https://doi.org/10.1080/01635581.2010.516478.

87. Zang J, Shen M, du S, Chen T, Zou S. The association between dairy intake and breast Cancer in Western and Asian populations: a systematic review and Meta-analysis. J Breast Cancer. 2015;18(4):313-22. https://doi.org/10.404 8/jbc.2015.18.4.313.

88. Dong JY, Zhang L, He K, Qin LQ. Dairy consumption and risk of breast cancer: a meta-analysis of prospective cohort studies. Breast Cancer Res Treat. 2011;127(1):23-31. https://doi.org/10.1007/s10549-011-1467-5.

89. Al Sarakbi W, Salhab M, Mokbel K. dairy products and breast cancer risk: a review of the literature. Int J Fertil Womens Med. 2005;50(6):244-9.

90. Ip C, Chin SF, Scimeca JA, Pariza MW. Mammary cancer prevention by conjugated dienoic derivative of linoleic acid. Cancer Res. 1991;51(22):611824.

91. Kritchevsky D. Antimutagenic and some other effects of conjugated linoleic acid. Br J Nutr. 2000;83(5):459-65. https://doi.org/10.1017/S0007114 500000581.

92. Lipkin $\mathrm{M}$, Newmark HL. Vitamin D, calcium and prevention of breast cancer: a review. J Am Coll Nutr. 1999;18(5 Suppl):392S-7S. https://doi.org/10.1080/ 07315724.1999.10718903.

93. Outwater JL, Nicholson A, Barnard N. Dairy products and breast cancer: the IGF-I, estrogen, and bGH hypothesis. Med Hypotheses. 1997;48(6):453-61. https://doi.org/10.1016/50306-9877(97)90110-9.

94. Thiebaut AC, et al. Dietary fat and postmenopausal invasive breast cancer in the National Institutes of Health-AARP Diet and health study cohort. J Natl Cancer Inst. 2007;99(6):451-62.

95. Jacobson EA, James KA, Newmark HL, Carroll KK. Effects of dietary fat, calcium, and vitamin D on growth and mammary tumorigenesis induced 
by 7,12-dimethylbenz(a) anthracene in female Sprague-Dawley rats. Cancer Res. 1989:49(22):6300-3.

96. Newmark HL. Vitamin D adequacy: a possible relationship to breast cancer. Adv Exp Med Biol. 1994;364:109-14. https://doi.org/10.1007/978-1-4615-251 0-3_11.

97. Jones Jl, Clemmons DR. Insulin-like growth factors and their binding proteins: biological actions. Endocr Rev. 1995;16(1):3-34. https://doi.org/1 0.1210/edrv-16-1-3.

98. Pietrzkowski Z, et al. Inhibition of growth of prostatic cancer cell lines by peptide analogues of insulin-like growth factor 1. Cancer Res. 1993;53(5): $1102-6$.

99. Aro A, Männistö S, Salminen I, Ovaskainen ML, Kataja V, Uusitupa M. Inverse association between dietary and serum conjugated linoleic acid and risk of breast cancer in postmenopausal women. Nutr Cancer. 2000;38(2):151-7. https://doi.org/10.1207/S15327914NC382_2.

100. Ritzenthaler $\mathrm{KL}$, et al. Estimation of conjugated linoleic acid intake by written dietary assessment methodologies underestimates actual intake evaluated by food duplicate methodology. J Nutr. 2001;131(5):1548-54.

101. Laden F, Hankinson SE, Spiegelman D, Neas LM, Colditz GA, Hunter DJ, et al. Geographic variation in breast cancer incidence rates in a cohort of U.S. women. J Natl Cancer Inst. 1997;89(18):1373-8. https://doi.org/10.1093/jnci/ 89.18.1373.

102. O'Shea M, Devery R, Lawless F, Murphy J, Stanton C. Milk fat conjugated linoleic acid (CLA) inhibits growth of human mammary MCF-7 cancer cells. Anticancer Res. 2000;20(5B):3591-601.

103. Gallardo M, Calaf GM. Curcumin inhibits invasive capabilities through epithelial mesenchymal transition in breast cancer cell lines. Int J Oncol. 2016;49(3):1019-27.

104. Hu XJ, et al. Genistein modulates the anti-tumor activity of cisplatin in MCF7 breast and HT-29 colon cancer cells. Arch Toxicol. 2014;88(3):625-35.

105. Lv ZD, et al. Curcumin induces apoptosis in breast cancer cells and inhibits tumor growth in vitro and in vivo. Int J Clin Exp Pathol. 2014;7(6):2818-24.

106. Redaniel MT, Gardner MP, Martin RM, Jeffreys M. The association of vitamin D supplementation with the risk of cancer in postmenopausal women. Cancer Causes Control. 2014;25(2):267-71. https://doi.org/10.1007/s10552013-0328-4.

107. de Moreno de Leblanc A, et al. Study of immune cells involved in the antitumor effect of kefir in a murine breast cancer model. J Dairy Sci. 2007; 90(4):1920-8. https://doi.org/10.3168/jds.2006-079.

108. Longhi G, et al. Microbiota and Cancer: the emerging beneficial role of Bifidobacteria in Cancer immunotherapy. Front Microbiol. 2020;11:575072.

109. Merenstein DJ, Smith KH, Scriven M, Roberts RF, Sanders ME, Petterson S. The study to investigate the potential benefits of probiotics in yogurt, a patientoriented, double-blind, cluster-randomised, placebo-controlled, clinical trial. Eur J Clin Nutr. 2010;64(7):685-91. https://doi.org/10.1038/ejcn.2010.30.

110. Kang SH, et al. The effects of dairy processes and storage on insulin-like growth factor-I (IGF-I) content in milk and in model IGF-I-fortified dairy products. J Dairy Sci. 2006;89(2):402-9.

111. Kiecolt-Glaser, J.K., Fagundes C.P., Andridge R., Peng J., Malarkey W.B., Habash D., Belury M.A., Depression, daily stressors and inflammatory responses to high-fat meals: when stress overrides healthier food choices. Mol Psychiatry, 2017. 22(3): p. 476-482, dois: https://doi.org/10.1038/mp.201 6.149 .

112. Kim MK, et al. Effects of steady low-intensity exercise on high-fat Diet stimulated breast Cancer progression via the alteration of macrophage polarization. Integr Cancer Ther. 2020;19:1534735420949678.

113. Picon-Ruiz M, Morata-Tarifa C, Valle-Goffin JJ, Friedman ER, Slingerland JM. Obesity and adverse breast cancer risk and outcome: mechanistic insights and strategies for intervention. CA Cancer J Clin. 2017;67(5):378-97. https:// doi.org/10.3322/caac.21405.

114. Pierobon M, Frankenfeld CL. Obesity as a risk factor for triple-negative breast cancers: a systematic review and meta-analysis. Breast Cancer Res Treat. 2013;137(1):307-14. https://doi.org/10.1007/s10549-012-2339-3.

115. Campbell PT, et al. Diabetes and cause-specific mortality in a prospective cohort of one million U.S. adults. Diabetes Care. 2012;35(9):1835-44.

116. Larsson SC, Mantzoros CS, Wolk A. Diabetes mellitus and risk of breast cancer: a meta-analysis. Int J Cancer. 2007;121(4):856-62. https://doi.org/10.1 002/ijc.22717.

117. Ben Q, Xu M, Ning X, Liu J, Hong S, Huang W, et al. Diabetes mellitus and risk of pancreatic cancer: a meta-analysis of cohort studies. Eur J Cancer. 2011;47(13):1928-37. https://doi.org/10.1016/j.ejca.2011.03.003.
118. Harding JL, Shaw JE, Peeters A, Cartensen B, Magliano DJ. Cancer risk among people with type 1 and type 2 diabetes: disentangling true associations, detection bias, and reverse causation. Diabetes care 2015;38: 264-270. Diabetes Care. 2015;38(4):734-5. https://doi.org/10.2337/dc15er04a.

119. Gallagher EJ, LeRoith D. Obesity and diabetes: the increased Risk of Cancer and Cancer-related mortality. Physiol Rev. 2015;95(3):727-48. https://doi. org/10.1152/physrev.00030.2014.

120. Li C, Yang L, Zhang D, Jiang W. Systematic review and meta-analysis suggest that dietary cholesterol intake increases risk of breast cancer. Nutr Res. 2016;36(7):627-35. https://doi.org/10.1016/..nutres.2016.04.009.

121. Llaverias G, Danilo C, Mercier I, Daumer K, Capozza F, Williams TM, et al. Role of cholesterol in the development and progression of breast cancer. Am J Pathol. 2011;178(1):402-12. https://doi.org/10.1016/j.ajpath.2010.11.005.

122. Reeves GK, Pirie K, Beral V, Green J, Spencer E, Bull D, et al. Cancer incidence and mortality in relation to body mass index in the million women study: cohort study. BMJ. 2007;335(7630):1134. https://doi.org/10.1136/bmj.39367.4 95995.AE.

123. Goodwin PJ, Stambolic V. Impact of the obesity epidemic on cancer. Annu Rev Med. 2015;66(1):281-96. https://doi.org/10.1146/annurev-med-051613012328.

124. Ley RE, Turnbaugh PJ, Klein S, Gordon Jl. Microbial ecology: human gut microbes associated with obesity. Nature. 2006;444(7122):1022-3. https:// doi.org/10.1038/4441022a.

125. Plottel CS, Blaser MJ. Microbiome and malignancy. Cell Host Microbe. 2011; 10(4):324-35. https://doi.org/10.1016/j.chom.2011.10.003.

126. Lamas B, Nachat-Kappes R, Goncalves-Mendes N, Mishellany F, Rossary A, Vasson MP, et al. Dietary fat without body weight gain increases in vivo MCF-7 human breast cancer cell growth and decreases natural killer cell cytotoxicity. Mol Carcinog. 2015;54(1):58-71. https://doi.org/10.1002/mc.22 074.

127. Turner LB. A meta-analysis of fat intake, reproduction, and breast cancer risk: an evolutionary perspective. Am J Hum Biol. 2011;23(5):601-8. https://doi. org/10.1002/ajhb.21176.

128. Schulz M, Hoffmann K, Weikert C, Nöthlings U, Schulze MB, Boeing H. Identification of a dietary pattern characterized by high-fat food choices associated with increased risk of breast cancer: the European prospective investigation into Cancer and nutrition (EPIC)-Potsdam study. Br J Nutr. 2008;100(5):942-6. https://doi.org/10.1017/S0007114508966149.

129. Sieri S, Krogh V, Ferrari P, Berrino F, Pala V, Thiébaut AC, et al. Dietary fat and breast cancer risk in the European prospective investigation into Cancer and nutrition. Am J Clin Nutr. 2008;88(5):1304-12. https://doi.org/1 0.3945/ajen.2008.26090.

130. Lin J, Manson JE, Lee IM, Cook NR, Buring JE, Zhang SM. Intakes of calcium and vitamin D and breast cancer risk in women. Arch Intern Med. 2007; 167(10):1050-9. https://doi.org/10.1001/archinte.167.10.1050.

131. Cho E, Spiegelman D, Hunter DJ, Chen WY, Stampfer MJ, Colditz GA, et al. Premenopausal fat intake and risk of breast cancer. J Natl Cancer Inst. 2003: 95(14):1079-85. https://doi.org/10.1093/jnci/95.14.1079.

132. Robien K, Cutler GJ, Lazovich D. Vitamin D intake and breast cancer risk in postmenopausal women: the lowa Women's health study. Cancer Causes Control. 2007;18(7):775-82. https://doi.org/10.1007/s10552-007-9020-x.

\section{Publisher's Note}

Springer Nature remains neutral with regard to jurisdictional claims in published maps and institutional affiliations.

\section{Ready to submit your research? Choose BMC and benefit from:}

- fast, convenient online submission

- thorough peer review by experienced researchers in your field

- rapid publication on acceptance

- support for research data, including large and complex data types

- gold Open Access which fosters wider collaboration and increased citations

- maximum visibility for your research: over $100 \mathrm{M}$ website views per year

At BMC, research is always in progress.

Learn more biomedcentral.com/submissions 